\title{
EFFECT OF IRRIGATION AND POTASH LEVELS ON GROWTH AND YIELD OF POTATO
}

\author{
R.C. Adhikari ${ }^{1}$ and M.K. Rana ${ }^{2}$
}

\begin{abstract}
The experiment comprising four levels of irrigation $(25,30,35$ and $40 \mathrm{~mm} C P E)$ and four levels of potash (0, 100, 125 and $150 \mathrm{~kg} / \mathrm{ha}$ ) was conducted in Haryana Agricultural University, Hisar during winter season of 201011 and 2011-12 to find out the optimum level of irrigation and potash for better growth and yield of potato. The potato variety used for the investigation was Kufri Bahar. The treatments were laid out in a split plot design with three replications keeping a net plot size of 3.6x3.6 m. The plant height at 45, 60, 75 and 90 days after planting, number of leaves per stem, leaves weight per hill, stem weight per hill, leaf area index and total and marketable tuber yield were significantly high with irrigation level $35 \mathrm{~mm}$ CPE and potash @ 150 $\mathrm{kg} / \mathrm{ha}$. The two years results suggest that the irrigation level $35 \mathrm{~mm}$ CPE in combination with potash@150 $\mathrm{kg} / \mathrm{ha}$ has shown the best treatment combination for potato production under semiarid conditions of Hisar (Haryna).
\end{abstract}

Keywords: Growth, irrigation, potato,potash, tuber yield

\section{INTRODUCTION}

Potato is a short duration, high yielding and nutrients exhaustive tuber crop. There are number of factors that play a crucial role in deciding the growth and yield of potato, however, irrigation and fertilization are the most predominating among them. Potato crop responds favorably to soil moisture but moisture in excess or in deficit declines its yield. Improper irrigation management practices not only waste the expensive and scarce water resources but also reduce the tuber yield and quality (Singh et al., 2002). Hence, it is possible to increase the production of potato by adopting well-scheduled irrigation programs throughout the growing season (Kashyap and Panda, 2003). Besides improving tuber quality, potash also plays an important role in growth and development of potato crop (Imas and Bansal, 2002), energy status of the plant, translocation and storage of assimilates and maintenance of plant-water relations (Marschner, 1995). It was, therefore, essential to formulate the efficient, reliable and economically viable irrigation management strategy with the use of potassium nutrient in order to produce higher potato yield.

\section{MATERIALS AND METHODS}

The present experiment was conducted at Research Farm of the Department of Vegetable Science Hisar during 2010-11 and 2011-12. The experimental soil was sandy loam in texture with pH 7.85, EC $0.23 \mathrm{dSm}-1$, organic carbon $0.44 \%$ and the available $\mathrm{N}, \mathrm{P}_{2} \mathrm{O}_{5}$ and $\mathrm{K}_{2} \mathrm{O} 156,15$ and $277 \mathrm{~kg} / \mathrm{ha}$, respectively. The treatments comprising four irrigation levels $(25,30,35$ and $40 \mathrm{~mm}$ CPE) and four potash levels $(0,100,125$ and $150 \mathrm{~kg} / \mathrm{ha}$ ) were laid-out in split plot design with three replications, keeping the irrigation levels in main plots and potash levels in sub-plots, and the depth of irrigation was kept $5 \mathrm{~cm}$. Individual net sub-plot was consisted of $12.96 \mathrm{~m}^{2}(3.60 \times 3.6 \mathrm{~m})$ with 6 rows, each row containing 18 plants. The crop was planted on 25th October in 2010 and 1st November in 2011. Two third dose of $\mathrm{N}$ and full doses of $\mathrm{P}$ and $\mathrm{K}$ were applied at the time of planting in furrows and the

$1 \quad$ NARC, Outreach Research Division, Khumaltar,Lalitpur, Nepal. Email: rcadhikari7@gmail.com

2 Department of Vegetable Science, CCS Haryana Agricultural University, Hisar-125 004, Haryana, India, E-mail: mkrlotus@gmail.com 
remaining one third dose of $\mathrm{N}$ was top dressed 5 weeks after planting. Disease free pre-sprouted seed tubers of variety Kufri Bahar weighing approximately 40-60 g were planted at a spacing of 60 $\mathrm{cm}$ between rows and $20 \mathrm{~cm}$ within row. Irrigation was scheduled as per the previous day pan evaporation data. Furrow method of irrigation was used to irrigate the experimental crop. The 1st post-planting common irrigation was given just after planting and the 2nd common irrigation was applied a week after 1st irrigation, thereafter, the differential irrigations were scheduled as per treatment. The recommended cultural practices were followed for raising a healthy crop. Ten plants were randomly selected from each plot to record the plant height $(\mathrm{cm})$ at 15 days intervals starting from 45 days after planting (DAP) to 90 days. The data on number of stems per hill, number of leaves per stem, leaf weight per hill (g), stem weight per hill (g) and leaf area index were recorded at the time of haulm killing and on marketable and total tuber yield $(\mathrm{q} / \mathrm{h})$ at harvest. The potato crop was dehaulmed 100 DAP and harvested 15 days after dehaulmed. The data recorded for various parameters were analyzed by using the techniques of analysis of variance (ANOVA) suggested by Gomez and Gomez (1984).

\section{RESULTS AND DISCUSSION}

\section{PLANT HEIGHT}

The irrigation levels differed significantly with respect to plant height at 45, 60, 75 and 90 days after planting during both the years (Table 1). The uppermost mean value for plant height at 45 $(55.7$ and $54.8 \mathrm{~cm}), 60(62.9$ and $60.4 \mathrm{~cm}), 75(63.9$ and $62.9 \mathrm{~cm})$ and $90(64.1$ and $63.6 \mathrm{~cm})$ DAP was recorded with irrigation level $35 \mathrm{~mm} \mathrm{CPE}$ and the lowest with irrigation level $25 \mathrm{~mm}$ CPE in 2010-11 and 2011-12, respectively. The data indicate that the plant height increased with the increase in irrigation level up to $35 \mathrm{~mm} \mathrm{CPE}$, and thereafter, it started declining with further increase in irrigation level $(40 \mathrm{~mm} C P E)$. It might be due to the fact that the crop encountered the favourable soil moisture conditions, which enhanced the availability of nutrients essentially required for the enlargement and elongation of plant cells. However, under excessive moisture (25 mm CPE) conditions especially in soils that are not too much porous, the plant roots are unable to get too much oxygen, which is very much essential for root respiration and uptake of nutrients ions. The results of present study are in conformation of the findings of Patel and Patel (2001), who noticed significant increase in plant height up to a CPE ratio of 1.75.

Table 1: Effect of irrigation and potash levels on plant height $(\mathrm{cm})$ of potato at $45,60,75$ and 90 DAP

\begin{tabular}{|c|c|c|c|c|c|c|c|c|}
\hline \multirow{3}{*}{ Treatments } & \multicolumn{8}{|c|}{ Plant height $(\mathrm{cm})$ days after planting (DAP) } \\
\hline & \multicolumn{4}{|c|}{ 2010-11 } & \multicolumn{4}{|c|}{ 2011-12 } \\
\hline & 45 & 60 & 75 & 90 & 45 & 60 & 75 & 90 \\
\hline \multicolumn{9}{|c|}{ Irrigation levels (I) } \\
\hline 25 mm CPE $\left(I_{1}\right)$ & 51.5 & 56.3 & 60.1 & 61.6 & 50.1 & 54.8 & 56.7 & 58.0 \\
\hline $30 \mathrm{~mm} \mathrm{CPE}\left(\mathrm{I}_{2}\right)$ & 53.0 & 60.0 & 62.2 & 62.6 & 52.6 & 58.9 & 61.1 & 62.3 \\
\hline 35 mm CPE $\left(I_{3}\right)$ & 55.7 & 62.9 & 63.9 & 64.1 & 54.8 & 60.4 & 62.9 & 63.6 \\
\hline $40 \mathrm{~mm} \mathrm{CPE}\left(\mathrm{I}_{4}\right)$ & 54.3 & 62.0 & 63.1 & 63.9 & 53.3 & 59.0 & 61.6 & 62.3 \\
\hline CD at $5 \%$ level & 3.16 & 3.12 & NS & NS & 3.15 & 3.10 & 2.17 & 2.18 \\
\hline
\end{tabular}




\begin{tabular}{|l|c|c|c|c|c|c|c|c|}
\hline Potash levels $(\mathrm{K})$ & \multicolumn{9}{|c|}{} \\
\hline $0 \mathrm{~kg} / \mathrm{ha}\left(\mathrm{K}_{1}\right)$ & 49.8 & 53.4 & 57.3 & 58.5 & 49.6 & 51.7 & 55.7 & 58.0 \\
\hline $100 \mathrm{~kg} / \mathrm{ha}\left(\mathrm{K}_{2}\right)$ & 53.5 & 58.0 & 61.3 & 62.3 & 52.8 & 56.3 & 60.8 & 63.1 \\
\hline $125 \mathrm{~kg} / \mathrm{ha}\left(\mathrm{K}_{3}\right)$ & 55.2 & 60.3 & 62.9 & 62.9 & 54.9 & 58.1 & 62.3 & 64.6 \\
\hline $150 \mathrm{~kg} / \mathrm{ha}\left(\mathrm{K}_{4}\right)$ & 56.7 & 61.2 & 63.6 & 64.7 & 55.8 & 59.6 & 64.4 & 66.8 \\
\hline CD at 5\% level & 3.58 & 4.00 & 4.00 & 3.70 & 2.58 & 2.42 & 5.03 & 5.03 \\
\hline Interaction (IxK) & NS & NS & NS & NS & NS & NS & NS & NS \\
\hline
\end{tabular}

In case of potash levels, all the treatments differed significantly with respect to plant height during both the years. The plant height of potato at 45, 60, 75 and 90 days after planting increased with the increase in potash level up to $35 \mathrm{~mm}$ CPE. The maximum plant height at $45(56.7$ and $55.8 \mathrm{~cm})$, $60(61.2$ and $59.6 \mathrm{~cm}), 75(63.6$ and $64.4 \mathrm{~cm})$ and $90(64.7$ and $66.8 \mathrm{~cm})$ DAP was recorded with potash application @ $150 \mathrm{~kg} / \mathrm{ha}$ in 2010-11 and 2011-12, respectively and the lowest with no potash application. The increments in plant height as a result of potash fertilization might be due to the role of potash in cell division and cell elongation, which as a result increased the plant height. Sharma (1994) also found that each successive increase in potash level from 0 to $90 \mathrm{~kg} / \mathrm{ha}$ significantly increased the plant height and recorded the maximum plant height with potash application @ $90 \mathrm{~kg} / \mathrm{ha}(45.30 \mathrm{~cm})$ and minimum $(33.85 \mathrm{~cm})$ with no potash application. Similarly, the present results are in good accordance with those obtained by Noor et al. (2011).

\section{NUMBER OF STEMS PER HILL}

The effect of various irrigation levels on number of stems per hill was not significant during both the years (Table 2). This might be due to the application of two common irrigations for uniform emergence of tubers, which might influence the number of stems per hill during the emergence. The number of stems per hill increased with the increase in potash level up to $150 \mathrm{~kg} / \mathrm{ha}$. The maximum mean number of stems per hill (3.83) was recorded with potash @ $150 \mathrm{~kg} / \mathrm{ha}$ followed by potash @ $125 \mathrm{~kg} / \mathrm{ha}$ (3.73) during the year 2010-11 and 2011-12. The results of present study corroborate the findings of Mahmoud and Hafez (2010), who found that the number of stems per hill increased significantly with increasing level of potash $(100-120 \mathrm{~kg} / \mathrm{ha})$. The interaction effect of irrigation and potash levels with respect to number of stems per hill was noticed statistically nonsignificant during both the years.

\section{NUMBER OF LEAVES PER STEM}

The effect of irrigation and potash levels played a vital role in the number of leaves per stem. The number of leaves per stem increased significantly with increasing levels of irrigation up to $35 \mathrm{~mm}$ CPE during both the years (Table 2). In potato, applying irrigation at $5 \mathrm{~cm}$ depth with irrigation level $35 \mathrm{~mm}$ CPE showed the maximum mean number of leaves per stem (13.7 and 13.6) followed by the irrigation level $40 \mathrm{~mm}$ CPE (13.0 and 12.9), while the plants with irrigation level $25 \mathrm{~mm}$ CPE showed the minimum number of leaves per stem (11.3 and 10.8) in 2010-11 and 2011-12, respectively. The results are in close compliance with the findings of Islam et al. (1990), who attained the significantly maximum number of compound leaves per plant (11.40) at irrigation level $40 \%$ depletion of available soil moisture in Bangladesh. 
It is evident from the data that the effect of different potash levels concerning the number of leaves per stem differed significantly from each other. The number of leaves per stem increased remarkably with the increase in potash level up to $150 \mathrm{~kg} / \mathrm{ha}$ (Table 2). The maximum number of leaves per stem was observed with potash application @ $150 \mathrm{~kg} / \mathrm{ha}$ (13.5 and 13.3) followed by potash @ $125 \mathrm{~kg} / \mathrm{ha}$ (13.0 and 12.8) in 2010-11 and 1011-12, respectively. The results of present study are similar to the findings of Mahmoud and Hafez (2010), who noticed that the number of leaves per stem increased significantly with increasing level of potash $(100-120 \mathrm{~kg} / \mathrm{ha})$ and the inimum number of leaves per stem with no potash application.

Table 2: Effect of irrigation and potash levels on number of stems per hill, number of leaves per stem, leaves weight per hill (g), stems weight per hill (g) and leaf area index at haulm pulling

\begin{tabular}{|c|c|c|c|c|c|c|}
\hline \multirow[b]{2}{*}{ Treatments } & \multicolumn{3}{|c|}{$2010-2011$} & \multicolumn{3}{|l|}{$2011-2012$} \\
\hline & $\begin{array}{c}\text { No. of } \\
\text { stems per } \\
\text { hill }\end{array}$ & $\begin{array}{c}\text { No. of } \\
\text { leaves per } \\
\text { stem }\end{array}$ & $\begin{array}{l}\text { Stems } \\
\text { weight } \\
\text { (g) per hill }\end{array}$ & $\begin{array}{c}\text { No. of } \\
\text { stems per hill }\end{array}$ & $\begin{array}{c}\text { No. of } \\
\text { leaves per } \\
\text { stem }\end{array}$ & $\begin{array}{l}\text { Stems } \\
\text { weight } \\
\text { (g) per hill }\end{array}$ \\
\hline \multicolumn{7}{|l|}{ Irrigation levels (I) } \\
\hline $25 \mathrm{~mm} \mathrm{CPE}\left(\mathrm{I}_{1}\right)$ & 3.61 & 11.3 & 53.4 & 3.55 & 10.8 & 52.4 \\
\hline $30 \mathrm{~mm}$ CPE $\left(\mathrm{I}_{2}\right)$ & 3.63 & 12.5 & 54.0 & 3.62 & 12.0 & 53.8 \\
\hline $35 \mathrm{~mm} \mathrm{CPE}\left(\mathrm{I}_{3}\right)$ & 3.74 & 13.7 & 54.8 & 3.75 & 13.6 & 54.7 \\
\hline $40 \mathrm{~mm} \mathrm{CPE}\left(\mathrm{I}_{4}\right)$ & 3.68 & 13.0 & 53.8 & 3.73 & 12.9 & 53.3 \\
\hline$C D$ at $5 \%$ level & NS & 1.62 & NS & NS & 1.94 & NS \\
\hline \multicolumn{7}{|l|}{ Potash levels (K) } \\
\hline $0 \mathrm{~kg} / \mathrm{ha}\left(\mathrm{K}_{1}\right)$ & 3.43 & 11.5 & 50.0 & 3.39 & 11.4 & 49.9 \\
\hline 100 kg/ha $\left(K_{2}\right)$ & 3.68 & 12.4 & 53.5 & 3.69 & 12.3 & 53.2 \\
\hline $125 \mathrm{~kg} / \mathrm{ha}\left(\mathrm{K}_{3}\right)$ & 3.73 & 13.0 & 55.2 & 3.73 & 12.8 & 55.0 \\
\hline 150 kg/ha $\left(K_{4}\right)$ & 3.83 & 13.5 & 56.9 & 3.83 & 13.3 & 56.3 \\
\hline CD at $5 \%$ level & 0.24 & 0.50 & 3.44 & 0.29 & 0.46 & 3.25 \\
\hline Interaction (IXK) & NS & NS & NS & NS & NS & NS \\
\hline
\end{tabular}




\section{STEM WEIGHT PER HILL}

The data presented in Table 2 show that the irrigation treatments not differed significantly with respect to stem weight per hill in both the years. In case of potash levels, all the treatments differed significantly with respect to stem weight per hill during both the years. The stem weight of potato increased with the increase in potash level up to $150 \mathrm{~kg} / \mathrm{ha}$. The maximum mean stem weight per hill ( 56.9 and $56.3 \mathrm{~g}$ ) was recorded when the potash was applied @ $150 \mathrm{~kg} / \mathrm{ha}$ followed by potash @ $125 \mathrm{~kg} / \mathrm{ha}(55.2$ and $55.0 \mathrm{~g})$ and the lowest stem weight (50.0 and $49.9 \mathrm{~g})$ was found with no application of potash in 2010-11 and 2011-12, respectively. The potash level 100 (53.5 and $53.2 \mathrm{~g}), 125(55.2$ and $55.0 \mathrm{~g})$ and $150 \mathrm{~kg} / \mathrm{ha}(56.9$ and $56.3 \mathrm{~g})$ were statistically at par with each other during 2010-11 and 2011-12, respectively. However, Mahmoud and Hafez (2010) reported that a potato crop supplied with potash @ $120 \mathrm{~kg} / \mathrm{fed}$ produced the maximum fresh weight of stems at 90 days after planting.

\section{LEAVES WEIGHT PER HILL}

The leaves weight per hill increased significantly with the increase in irrigation levels up to $35 \mathrm{~mm}$ CPE (Table 2). In 2010-11, the significantly highest mean value for leaves weight per hill was recorded with irrigation level $35 \mathrm{~mm} \mathrm{CPE} \mathrm{(149.0} \mathrm{and} 146.2 \mathrm{~g})$ followed by $40 \mathrm{~mm}$ CPE (144.2 and $144.3 \mathrm{~g}$ ) in 2010-11 and 2011-12, respectively. The minimum leaves weight per hill (136.6 and 134. 0 g) was measured with irrigation level $25 \mathrm{~mm}$ CPE in both the years. The irrigation level $25(136.6 \mathrm{~g})$ and $30 \mathrm{~mm} \mathrm{CPE}(139.6 \mathrm{~g})$ were statistically at par with each other in 2010-11. Similarly, during 2011-12, the irrigation level 25 (134.0 g) and $30 \mathrm{~mm} \mathrm{CPE} \mathrm{(136.6} \mathrm{g)} \mathrm{and} 35$ (146.2 g) and $40 \mathrm{~mm}$ CPE $(144.3 \mathrm{~g})$ were statistically at par with each other. The results of present study confirmed the findings of Amanullah et al. (2010), who found that irrigation at IW/CPE ratio of 1.00 produced the statistically highest fresh weight of haulms per hill.

The average leaves weight per hill increased significantly with the increase in level of potash up to $150 \mathrm{~kg} / \mathrm{ha}$. The maximum leaves weight per hill (151.2 and $149.9 \mathrm{~g})$ was noted with potash @ 150 $\mathrm{kg} / \mathrm{ha}$ and the minimum with no potash application (128.3 and 128.7 g) in 2010-11 and 2011-12, respectively. Similar results were obtained by Mahmoud and Hafez (2010), who observed that the fresh weight of leaves increased significantly with increasing potash level from 40 to $120 \mathrm{~kg} / \mathrm{fed}$ and obtained the maximum weight of leaves per hill with potash application @ $120 \mathrm{~kg} / \mathrm{fed}$ and the minimum with potash @ $40 \mathrm{~kg} / \mathrm{fed}$ at 90 days after planting.

The interaction effect of various irrigation and potash levels differed significantly for various treatment combinations. The significantly maximum (156.9 and $154.7 \mathrm{~g}$ ) average leaves weight per hill was recorded with treatment combination irrigation level $35 \mathrm{~mm}$ CPE and potash $150 \mathrm{~kg} / \mathrm{ha}$ and the minimum (124.4 and $123.1 \mathrm{~g})$ with treatment combination irrigation level $25 \mathrm{~mm}$ CPE and potash $0 \mathrm{~kg} / \mathrm{ha}$ in 2010-11 and 2010-12, respectively. These results support the findings of Noor et al. (2011). Nitrogen and phosphorus application to all the treatments at constant rate in combination with potash might enhance the nitrogen use efficiency, and thus, the availability of nitrogen in proper quantity might increase the leaves weight. 


\section{LEAF AREA INDEX}

In potato, leaf area index is an indicator of growth and it explains the rate of leaf expansion due to irrigation and potash treatments. The irrigation treatment $35 \mathrm{~mm}$ CPE showed the significantly highest value for leaf area index during both the years (Table 3 ). The maximum mean leaf area index (2.77 and 2.60) was recorded with irrigation level $35 \mathrm{~mm}$ CPE followed by $40 \mathrm{~mm}$ CPE (2.69 and 2.53), while the lowest value for leaf area index (2.57 and 2.39) was observed with irrigation level $25 \mathrm{~mm}$ CPE in 2010-11 and 2011-12, respectively. This indicates that the effect of irrigation treatment on leaves longevity as well as on the maximum leaf area or percent ground cover might influence the net carbon gain (Wolfe et al., 1983) but Khalak and Kumaraswamy (1992) obtained the significantly highest leaf area index with $40 \mathrm{~mm}$ at IW/CPE ratio of 1.0.

Table 3: Effect of irrigation and potash levels on , leaves weight per hill $(g)$ and leaf area index at haulm pulling, marketable and total tuber yield of potato $(q / h a)$ at harvest

\begin{tabular}{|c|c|c|c|c|c|c|c|c|}
\hline \multirow[b]{2}{*}{ Treatment } & \multicolumn{4}{|c|}{ 2010-11 } & \multicolumn{4}{|c|}{ 2011-12 } \\
\hline & $\begin{array}{c}\text { Leaves } \\
\text { weight } \\
\text { (g) per hill }\end{array}$ & $\begin{array}{l}\text { Leaf } \\
\text { area } \\
\text { index }\end{array}$ & $\begin{array}{c}\text { Marketabl } \\
\text { e yield } \\
\text { (q/ha) }\end{array}$ & $\begin{array}{l}\text { Total } \\
\text { yield } \\
\text { (q/ha) }\end{array}$ & $\begin{array}{c}\text { Leaves } \\
\text { weight } \\
\text { (g) per hill }\end{array}$ & $\begin{array}{l}\text { Leaf } \\
\text { area } \\
\text { index }\end{array}$ & $\begin{array}{c}\text { Marketa } \\
\text { ble yield } \\
\text { (q/ha) }\end{array}$ & $\begin{array}{l}\text { Total } \\
\text { yield } \\
\text { (q/ha) }\end{array}$ \\
\hline \multicolumn{9}{|c|}{ Irrigation levels (I) } \\
\hline 25 mm CPE $\left(I_{1}\right)$ & 136.6 & 2.57 & 306.3 & 326.5 & 134.0 & 2.39 & 279.6 & 300.5 \\
\hline 30 mm CPE $\left(I_{2}\right)$ & 139.6 & 2.63 & 352.9 & 370.5 & 136.6 & 2.48 & 317.2 & 337.2 \\
\hline 35 mm CPE $\left(I_{3}\right)$ & 149.0 & 2.77 & 389.2 & 406.4 & 146.2 & 2.60 & 357.3 & 374.6 \\
\hline 40 mm CPE $\left(I_{4}\right)$ & 144.2 & 2.69 & 367.6 & 381.5 & 144.3 & 2.53 & 336.5 & 349.6 \\
\hline CD at $5 \%$ level & 3.08 & 0.03 & 18.3 & 23.2 & 6.92 & 0.03 & 16.1 & 22.2 \\
\hline \multicolumn{9}{|l|}{ Potash levels (K) } \\
\hline $0 \mathrm{~kg} / \mathrm{ha}\left(\mathrm{K}_{1}\right)$ & 128.3 & 2.49 & 300.0 & 319.8 & 128.7 & 2.34 & 278.5 & 298.0 \\
\hline $100 \mathrm{~kg} / \mathrm{ha}\left(\mathrm{K}_{2}\right)$ & 141.3 & 2.64 & 352.2 & 370.0 & 138.5 & 2.48 & 315.7 & 334.0 \\
\hline $125 \mathrm{~kg} / \mathrm{ha}\left(\mathrm{K}_{3}\right)$ & 146.2 & 2.72 & 371.5 & 388.2 & 144.0 & 2.56 & 337.5 & 354.9 \\
\hline $150 \mathrm{~kg} / \mathrm{ha}\left(\mathrm{K}_{4}\right)$ & 151.2 & 2.81 & 392.3 & 406.7 & 149.9 & 2.64 & 358.8 & 374.9 \\
\hline CD at $5 \%$ level & 4.22 & 0.03 & 17.4 & 18.0 & 4.94 & 0.02 & 12.2 & 16.1 \\
\hline \multicolumn{9}{|l|}{ Interaction (IXK) } \\
\hline $\mathrm{I}_{1} \mathrm{XK}_{1}$ & 124.4 & 2.34 & 264.2 & 285.7 & 123.1 & 2.19 & 241.2 & 263.9 \\
\hline $\mathrm{I}_{1} \mathrm{XK}_{2}$ & 133.5 & 2.54 & 304.8 & 325.8 & 131.8 & 2.36 & 270.5 & 292.7 \\
\hline $\mathrm{I}_{1} \mathrm{XK}_{3}$ & 142.7 & 2.65 & 321.9 & 341.5 & 138.3 & 2.45 & 293.2 & 313.5 \\
\hline $\mathrm{I}_{1} \mathrm{XK}_{4}$ & 146.0 & 2.74 & 334.4 & 352.7 & 142.9 & 2.55 & 313.3 & 332.0 \\
\hline $\mathrm{I}_{2} \times \mathrm{K}_{1}$ & 127.9 & 2.46 & 292.1 & 312.1 & 125.5 & 2.32 & 272.4 & 294.2 \\
\hline
\end{tabular}




\begin{tabular}{|l|l|l|l|l|l|l|l|l|}
\hline $\mathrm{I}_{2} \mathrm{KK}_{2}$ & 138.5 & 2.61 & 353.7 & 372.3 & 134.5 & 2.46 & 309.4 & 330.0 \\
\hline $\mathrm{I}_{2} \times \mathrm{K}_{3}$ & 142.7 & 2.67 & 373.7 & 391.3 & 139.7 & 2.53 & 332.3 & 351.9 \\
\hline $\mathrm{I}_{2} \times K_{4}$ & 149.3 & 2.78 & 392.0 & 406.0 & 146.8 & 2.61 & 354.7 & 372.7 \\
\hline $\mathrm{I}_{3} \times K_{1}$ & 142.7 & 2.62 & 331.0 & 351.3 & 135.3 & 2.46 & 308.1 & 326.4 \\
\hline $\mathrm{I}_{3} \times K_{2}$ & 137.3 & 2.75 & 383.3 & 400.7 & 144.0 & 2.58 & 353.1 & 370.1 \\
\hline $\mathrm{I}_{3} \times K_{3}$ & 148.8 & 2.81 & 404.7 & 421.3 & 150.9 & 2.65 & 371.7 & 389.4 \\
\hline $\mathrm{I}_{3} \times K_{4}$ & 153.0 & 2.89 & 437.9 & 452.2 & 154.7 & 2.72 & 396.1 & 412.3 \\
\hline $\mathrm{I}_{4} \times K_{1}$ & 131.7 & 2.53 & 312.5 & 329.9 & 131.0 & 2.37 & 292.2 & 307.6 \\
\hline $\mathrm{I}_{4} \times K_{2}$ & 144.3 & 2.66 & 367.0 & 381.3 & 143.8 & 2.51 & 329.7 & 343.4 \\
\hline $\mathrm{I}_{4} \times K_{3}$ & 148.2 & 2.73 & 385.8 & 398.8 & 147.0 & 2.59 & 352.9 & 365.0 \\
\hline $\mathrm{I}_{4} \times K_{4}$ & 152.4 & 2.83 & 404.9 & 416.0 & 144.3 & 2.66 & 371.1 & 382.5 \\
\hline $\mathrm{CD}$ at 5\% level & 8.44 & 0.06 & 34.8 & 36.0 & 9.88 & 0.04 & 24.4 & 32.2 \\
\hline
\end{tabular}

Increasing level of potash up to $150 \mathrm{~kg} / \mathrm{ha}$ increased the leaf area index, and the maximum value for leaf area index was recorded with potash application @ $150 \mathrm{~kg} / \mathrm{ha}$ during both the years. Similar effect of potash on leaf area index was reported by Saikia et al. (1987), who observed a beneficial influence of potash application on leaf area index and also in retaining more leaf area until maturity and recorded the maximum leaf area index $(0.81)$ with potash level $150 \mathrm{~kg} / \mathrm{ha}$ and minimum with no potash application (0.66)

The interaction among the treatment combinations differed significantly from each other with respect to leaf area index in 2010-11 and 2011-12. The present results indicated that the interaction effect showed considerable variation among the treatment combinations for leaf area index. The treatment combination irrigation level $35 \mathrm{~mm}$ CPE along with potash application @ $15 \mathrm{~kg} / \mathrm{ha}$ showed the best result with respect to leaf area index. The increase in leaf area index might be due to better root and shoot growth, generally enhanced by potash with beneficial soil moisture regime. The increase in leaf area index is closely related to leaf area duration (Wolfe et al., 1983) or to cumulative light interception (Jefferies and Mackerron, 1993).

\section{TOTAL TUBER YIELD}

The total tuber yield per hectare improved markedly with the increase in irrigation level up to 35 $\mathrm{mm} \mathrm{CPE} \mathrm{(Table} \mathrm{3).} \mathrm{The} \mathrm{maximum} \mathrm{mean} \mathrm{value} \mathrm{for} \mathrm{total} \mathrm{tuber} \mathrm{yield}(406.4$ and $374.6 \mathrm{q} / \mathrm{ha}$ ) was recorded with irrigation level $35 \mathrm{~mm}$ CPE followed by $40 \mathrm{~mm} \mathrm{CPE} \mathrm{(381.5} \mathrm{and} 349.6 \mathrm{q} / \mathrm{ha})$ and the smallest mean value ( 326.5 and $300.5 \mathrm{q} / \mathrm{ha}$ ) with irrigation level $25 \mathrm{~mm} \mathrm{CPE}$ in 2010-11 and 2011-12, respectively. Similar effect of irrigation on total tuber yield $(\mathrm{q} / \mathrm{ha})$ was reported by Sharma and Dixit (1992), who found that the irrigation at $33 \mathrm{~mm}$ CPE gave the maximum tuber yield (q/ha). This might be due to the increase in yield contributing characters and higher uptake of nutrients. Potato showed a reduction in yield in the treatment receiving water at $25 \mathrm{~mm} \mathrm{CPE}$. This treatment also produced many tubers with enlarged lenticels, which might be a response of potato crop to excessive moisture conditions.

The levels of potash differed significantly from each other with respect to total tuber yield. The total tuber yield per hectare enhanced remarkably with the increase in potash level up to 150 
$\mathrm{kg} / \mathrm{ha}$. The maximum total tuber yield was attained when potash was applied @ $150 \mathrm{~kg} / \mathrm{ha}(406.7$ and $374.9 \mathrm{q} / \mathrm{ha}$ ) followed by potash @ $125 \mathrm{~kg} / \mathrm{ha}(388.2$ and $354.9 \mathrm{q} / \mathrm{ha})$ and the lowest total tuber yield with no potash application (319.8 and $298.0 \mathrm{q} / \mathrm{ha})$. Similar effect of potash on total tuber yield ( $q /$ ha) was reported by Deka and Dutta (2000), who obtained the highest tuber yield with potash application @ $100 \mathrm{~kg} / \mathrm{ha}$.

The interaction of various irrigation levels with different levels of potash indicated remarkable variation for total tuber yield. The maximum total tuber yield $(452.2$ and $412.3 \mathrm{q} / \mathrm{ha}$ ) was harvested from a treatment combination irrigation level $35 \mathrm{~mm}$ CPE and potash @ $150 \mathrm{~kg} / \mathrm{ha}$ and the minimum ( 285.7 and $263.9 \mathrm{q} / \mathrm{ha}$ ) from the treatment combination of irrigation level $25 \mathrm{~mm} \mathrm{CPE}$ with no potash application during 2010-11 and 2011-12, respectively. The increase in tuber yield (q/ha) might be attributed to improved haulm growth, increased photosynthesis and greater mobilization of photosynthates towards tuber formation sites due to best combination of soil moisture and nutrients availability.

\section{MARKETABLE TUBER YIELD}

The marketable tuber yield per hectare improved significantly with the increase in irrigation level up to $35 \mathrm{~mm}$ CPE (Table 4). The maximum mean value for marketable tuber yield ( 389.2 and 357.3 (q/ha) was recorded with irrigation level $35 \mathrm{~mm}$ CPE followed by $40 \mathrm{~mm}$ CPE (367.6 and $336.5 \mathrm{q} / \mathrm{ha}$ ) and the smallest mean value for marketable tuber yield (306.3 and $279.6 \mathrm{q} / \mathrm{ha}$ ) with irrigation level $25 \mathrm{~mm}$ CPE in 2010-11 and 2011-12, respectively.

The potash levels differed significantly from each other with respect to marketable tuber yield (q/ha), which enhanced remarkably with the increase in potash level up to $150 \mathrm{~kg} / \mathrm{ha}$. The maximum marketable tuber yield was attained when potash was applied @ $150 \mathrm{~kg} / \mathrm{ha}(392.3$ and $358.8 \mathrm{q} / \mathrm{ha})$ followed by potash @ $125 \mathrm{~kg} / \mathrm{ha}(371.5$ and $337.5 \mathrm{q} / \mathrm{ha})$ and the lowest with no potash application (300.0 and $278.5 \mathrm{q} / \mathrm{ha}$ ) in 2010-11 and 2011-12, respectively. Similar effect of potash on marketable tuber yield was reported by Deka and Dutta (2000), who noticed that the application of potash significantly increased the marketable tuber yield. In fact, potash is known to play an important role in the synthesis and translocation of photosynthates from leaves to the tubers (Reddy et al. 1986).

The interaction of various irrigation levels with different potash levels indicated incredible variation in marketable tuber yield per hectare. The maximum marketable tuber yield per hectare (437.9 and $396.1 \mathrm{q} / \mathrm{ha}$ ) was obtained with a treatment combination irrigation level $35 \mathrm{~mm}$ CPE and potash @ $150 \mathrm{~kg} / \mathrm{ha}$ and the minimum ( 264.2 and $241.2 \mathrm{q} / \mathrm{ha})$ with treatment combination irrigation level 25 $\mathrm{mm}$ CPE and no potash application during the year 2010-11 and 2011-12, respectively. The increase in marketable tuber yield might be attributed to better haulm growth, increased photosynthesis and greater mobilization of photosynthates towards tuber production sites due to the best combination of soil moisture and nutrients availability. These results concur with earlier reports of McDole (1978).

\section{CONCLUSION}

Based on experimental results, it is concluded that the various levels of irrigation and potash improved the growth and yield of potatoes. Irrigation level $35 \mathrm{~mm} \mathrm{CPE}$ with potash @ $150 \mathrm{~kg} / \mathrm{ha}$ was superior for best growth and yield of potato under semi-arid conditions of Haryana. 


\section{REFERENCES}

Amanullah, A.S.M., Talukder, S.U., Sarkar, A.A. and Ahsanullah, A.S.M., 2010. Yield and water use efficiency of four potato varieties under different irrigation regimes. Bangladesh Research Publications Journal 4: 254-264.

Deka, N.C, and Dutta, T.C., 2000. Effect of potassium on yield and economics of potato cultivation in acidic soil of Assam. Journal of Potassium Research 16: 77-79.

Gomez, K.A. and Gomez, A., 1984. Statistical Procedure for Agricultural Research, 2ned. New York: John Willy and Sons USA.

Imas, P. and Bansal, S.K., 2002. Potassium and integrated nutrient management in potato. In: Potato Global Research and Development, Vol. II (Eds. Khurana, S.M.P., Shekhawat, G.S., Pandey, S.K. and Singh, B.P.). Indian Potato Association, Shimla, Himachal Pradesh, India, pp. 744-754.

Islam, T., Sarker, H., Alam, J. and Rashid, H.U., 1990. Water use and yield relationships of irrigated potato. Agricultural Water Management 18: 173-179.

Jefferies, R.A. and Mackerron, D.K.L., 1993. Response of potato genotypes to drought. II. Leaf area index, growth and yield. Annals of Applied Biology 122: 105-112.

Kashyap, P.S. and Panda, R.K., 2003. Effect of irrigation scheduling on potato crop parameters under water stressed conditions. Agricultural Water Management 59: 49-66.

Khalak, A. and Kumaraswamy, A.S., 1992. Effect of irrigation schedule and mulch on growth attributes and dry matter accumulation in potato (Solanum tuberosum). Indian Journal of Agronomy 37: 510-513.

Mahmoud, A.R. and Hafez, M.M., 2010. Increasing productivity of potato plants (Solanum tuberosum L.) by using potassium fertilizer and humic acid application. International Journal of Academic Research 2: 83-88.

Marschner, H., 1995. Mineral Nutrition of Higher Plants, $2^{\text {nd }}$ ed. London: Academic Press, United Kingdom.

McDole, R.E. 1978. Potassium fertilizer trial with potatoes in coarse textured oils in southern-eastern Idaho. American Potato Journal 55:161-170.

Noor, M.A., Pervez, M.A., Ayyub, C.M. and Ahmad, R., 2011. Physio-morphological determination of potato crop regulated by potassium sources management. Journal of Agricultural Research 49: 233-240.

Patel J C and Patel L R. 2001. Effect of irrigation and nitrogen on yield attributes in potato. Journal of Indian Potato Association, 28(2-4): 285-287.

Reddy, D.V., Arora, P.N. and Sharma, R.P., 1986.Effect of different doses of P and K on the growth and tuber yield of potato varieties. Indian Journal of Agricultural Science 56: 497-502.

Saikia, L., Patgiri, D.K. and Mahanta, T.C., 1987. Effect of levels of potash on the growth of potato varieties. Journal of Potassium Research 3(2): 80-84.

Sharma, J.P., 1994. Production potential and economics of potato under different schedules of irrigation, levels of potassium and method of weed control. Journal of Potassium Research 10(3): 278-281.

Sharma, S.K. and Dixit, R.S., 1992. Effect of irrigation and planting techniques on tuber yield of potato (Solanum tuberosum L.). Indian Journal of Agronomy 37: 763-768.

Singh, N., Sood, M.C. and Sharma, R.C., 2002. Effect of irrigation levels, cultural practices and nitrogen application on potato production under drip and sprinkler methods of irrigation. In: Potato Global Research and Development, Vol. II (Eds. Khurana, S.M.P., Shekhawat, G.S., Pandey, S.K. and Singh, B.P.). Indian Potato Association, Shimla, Himachal Pradesh, India, pp. 923-925.

Wolfe, D.W., Fereres, E. and Voss, R.E., 1983. Growth and yield response to two potato cultivars to various levels of applied water. Irrigation Science 3: 211-222. 